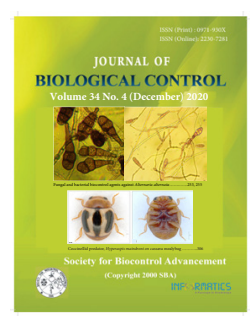

\title{
Predatory potential of Cryptolaemus montrouzieri Mulsant on mealybugs and aphids
}

\author{
S. R. SURWASE*, S. S. SHETGAR and S. H. TIMKE \\ Department of Agricultural Entomology, College of Agriculture, (Vasantrao Naik Marathwada Agricultural University), Latur- \\ 413512, Parbhani, Maharashtra, India \\ *Corresponding author E-mail: surwaseseema333@rediffmail.com
}

\begin{abstract}
The predatory potential of Cryptolaemus montrouzieri Mulsant on mealybugs and aphids viz, Maconellicoccus hirsutus, Phenacoccus solenopsis and Aphis gossypii was studied at the Biocontrol Agents Laboratory, Department of Agricultural Entomology, College of Agriculture, Latur at the temperature of $25 \pm 2^{\circ} \mathrm{C}$ maintained in BOD incubator during year 2013-14. The consumption rate of grubs and beetles of $C$. montrouzieri was in order of $A$. gossypii $>M$. hirsutus $>$ P. solenopsis.
\end{abstract}

KEY WORDS: Aphids, ladybird beetle, mealybugs, predator

(Article chronicle: Received: 22-07-2019; Revised: 09-10-2020; Accepted: 12-10-2020)

Sucking pests that include mealybugs and aphids have been reported as serious pests of grapevine, cotton and several crops in India. Grape production is often adversely affected due to the mealybugs to the extent of damage being as much as 100 per cent in extreme cases in India (Babu and Azam, 1989). Infestation of mealybug on leaves, shoots, nodes, fruits and branches especially on growing point of the plant results in malformation of leaves and tips of shoots. The pink hibiscus mealybug, Maconellicoccus hirsutus (Green) (Hemiptera: Pseudococcidae) was commonly found causing wide spread damage to many grape growing areas in India (Mani and Thontadarya, 1987a). Similarly, cotton mealybug, Phenacoccus solenopsis Tinsely (Hemiptera: Pseudococcidae), a soft-bodied sucking insect is inflicting severe damage to the several commercial plants. Aphid, Aphis gossypii Glover (Hemiptera: Aphididae) is another key pest of the cotton crop. The management of these sucking pest is becoming difficult and one of the benign alternatives is the use of biocontrol agents.

The coccinellids have emerged as strong and potent biocontrol agents and result oriented researches are further needed continuously to ascertain their efficiency in the integrated pest management programme. Hence, keeping this in view, the investigations on predatory potential of Cryptolaemus montrouzieri Mulsant on mealybugs and aphids were carried out.
The culture of C. montrouzieri was obtained from ICARNational Bureau of Agricultural Insect Resources, Bengaluru for these studies.

\section{Mass multiplication of $M$. hirsutus on pumpkins}

The laboratory technique of rearing of mealybugs on ripe red pumpkins, Cucurbita maxima standardized by Chacko et al. (1978) and Singh (1978) was followed. The red ripe pumpkins having ridges and grooves with small stalk were used for multiplication of mealybugs. The pumpkins were washed with tap water to remove dust particles and then dipped in a solution of Bavistin 0.1 per cent to kill the pathogens. The injured pumpkins were discarded and minor wounds were plugged with hot paraffin wax and then dried. For shallow groove-less pumpkins, a simple roping technique was followed. This facilitated rapid multiplication of mealybugs on shallow grooves and groove-less pumpkins. Care was taken to treat the ropes "Sutali" with Bavistin solution. The rearing cages having size of $30 \times 30 \times 30 \mathrm{~cm}$ with slanting glass top were used for multiplication of mealybugs. All other sides of cages were fitted with 40 guage nylon mesh with the provision of sleeve on front side. The care was taken to close all cracks and crevices of the wooden cages to prevent escape of early instars of the mealybugs. 


\section{Inoculation of egg masses of mealybug on pumpkins}

The pumpkins were inoculated with egg masses of $M$. hirsutus with the help of wet camel hair brush. Number of egg sacs placed on each pumpkin varied according to size of pumpkin. The pumpkins were then kept in wooden cages. The inoculation was done with ovisacs of $M$. hirsutus throughout period of study. The ambient temperature and relative humidity of the laboratory ranged from $25^{\circ} \mathrm{C}$ to $30^{\circ} \mathrm{C}$ and 65 to 75 per cent, respectively.

\section{Mass multiplication of $\boldsymbol{P}$. solenopsis on potato}

The laboratory technique of rearing of mealybugs on potato sprouts reported by Branigan (1916) and further modified by Smith and Armitage (1920) and elaborated by Fisher (1963) was followed. The bold healthy potatoes were brought from the market. These potatoes were washed gently with tap water to remove any surface residue of insecticide. Such potatoes were surface treated with carbendazim $50 \mathrm{WP}$ at the rate of $1 \mathrm{~g} /$ litre of water to prevent rotting. The sandy and light soil was used for growing potatoes. The soil was sterilized by formalin before potato plantation. The plastic pots having $26 \mathrm{~cm}$ diameter and $24 \mathrm{~cm}$ height were used for growing the potatoes. After sowing, potatoes were slightly covered with soil. The pots were watered regularly. The potatoes were well sprouted in 10 to 12 days. On such sprouted potatoes the ovisacs of $P$. solenopsis were transferred. The mass culture of mealybugs was maintained throughout the period of investigation.

\section{Mass multiplication of $\boldsymbol{A}$. gossypii on cotton}

The culture of aphids was obtained from the pesticide free cotton variety NH-630 sown in a plot size of 5 x 5 sq.m at the spacing of $45 \times 10 \mathrm{~cm}$.

\section{Multiplication of $C$. montrouzieri}

Six pairs of newly emerged beetles of $C$. montrouzieri grown on respective prey were transferred into each petridish of $10 \times 2 \mathrm{~cm}$ size. The respective species of mealybugs and aphids were provided to these beetles as food. After completing pre-mating and pre-oviposition period, the females of $C$. montrouzieri laid eggs near the mealybugs/ aphids kept in petridish. Such petridishes were observed daily to obtain the eggs of C. montrouzieri.

The studies on predatory potential of $C$. montrouzieri on third instar nymphs of species of mealybugs viz., $M$. hirsutus and $P$. solenopsis and aphids viz., A. gossypii were carried out in completely randomized design replicated five times at $25 \pm 2^{\circ} \mathrm{C}$ temperature maintained in BOD incubator. Fifty grubs of predator comprising of 10 grubs in each replication were used to feed upon the respective preys separately.
The known numbers of preys were provided to grubs of $C$. montrouzieri daily until pupation. The observations on the number of prey consumed by each of larval instars of $C$. montrouzieri were recorded daily after 24 hours of its exposure till pupation. The male and female beetles of $C$. montrouzieri which were emerged from their immature stages fed on respective prey were used to record the observation on their feeding potential daily on each of the preys under investigation. An average weight of 10 third instar nymphs of respective species of mealybugs and aphids was recorded. The data on predatory potential in terms of number were converted into predatory potential on weight basis.

The results on predatory potential of grubs of $C$. montrouzieri on mealybugs and aphids are presented in (Table 1). The significantly minimum duration to the extent of 22.99 days was required to complete the entire development of $C$. montrouzieri by feeding on 103.38 third instar nymphs of P. solenopsis followed by 25.02 days by feeding on 136.08 nymphs of $M$. hirsutus and 28.30 days by feeding on 688.93 nymphs of $A$. gossypii. However, I, II, III and IV instar larvae consumed significantly minimum number of third instar nymphs of $P$. solenopsis followed by $M$. hirsutus to the extent of $10.10,21.09,44.11$ and 60.77 , respectively and $A$. gossypii to the tune of $54.24,107.06,212.50$ and 315.20 , respectively (Table 2).

Mani and Thontadarya (1987b) reported that the single I, II, III and IV instar grub of C. montrouzieri consumed on an average 4,11, 80 and 164 nymphs of $M$. hirsutus, respectively. Babu and Azam (1987) found that I, II, III and IV instar larvae of $C$. montrouzieri consumed 6.9, 42.1, 140.1 and 354.7 nymphs of $M$. hirsutus, respectively. According to Naik et al. (2003), I, II, III and IV instar grub of C. montrouzieri consumed 3, 9, 64 and 156 nymphs of M. hirsutus. Fand et al. (2010) reported that I, II, III and IV instar grub of C. montrouzieri consumed 5.40, 8.20, 19.40 and 32.60 III nymphal instar of P. solenopsis.

The male and female adult beetles of $C$. montrouzieri consumed 770.12 and 917.80 of A. gossypii, 402.38 and 589.60 of $M$. hirsutus and 383.95 and 476.00 of $P$. solenopsis in a period of 54 and 62, 77 and 107, 84 and 96 days, respectively (Table 3 ). It indicate that the feeding potential of female was more than males. Al Khateeb and Raje (2001) reported that the predation rate of male beetle of $C$. montrouzieri on third nymphal instar of $P$. citri was $37.7 \pm 3.51$. Kulkarni (2000) reported that male predatory beetle consumed 521.37 (34.60 days) and 328.50 (30.03 days) nymphs of $M$. hirsutus and F. virgata, respectively. Deokar (2011) and Gore (2012) reported the consumption of 733.60 and 636.20 of II instar nymphs of $M$. hirsutus and $P$. solenopsis, respectively by male beetle of $C$. montrouzieri during its development. The female 
Predatory potential of Cryptolaemus montrouzieri on mealybugs and aphids

Table 1. The mean larval instar duration of $C$. montrouzieri on mealy bugs and aphids

\begin{tabular}{|c|c|c|c|c|c|c|}
\hline \multirow[t]{2}{*}{ Name of prey } & \multicolumn{4}{|c|}{ Larval instars } & \multirow[t]{2}{*}{ Total } & \multirow[t]{2}{*}{ Mean } \\
\hline & I & II & III & IV & & \\
\hline A. gossypii & 5.97 & 5.32 & 8.17 & 8.84 & 28.30 & 5.66 \\
\hline M. hirsutus & 4.94 & 4.51 & 7.48 & 8.09 & 25.02 & 5.00 \\
\hline P. solenopsis & 4.48 & 4.36 & 6.79 & 7.36 & 22.99 & 4.60 \\
\hline S.E. + & 0.06 & 0.03 & 0.07 & 0.05 & - & - \\
\hline C.D. at $5 \%$ & 0.19 & 0.09 & 0.22 & 0.16 & - & - \\
\hline C.V. $(\%)$ & 2.71 & 1.49 & 2.13 & 1.51 & - & - \\
\hline
\end{tabular}

Table 2. Feeding potential of grubs of $C$. montrouzieri on mealy bugs and aphids

\begin{tabular}{|c|c|c|c|c|c|c|}
\hline \multirow{2}{*}{ Parameter } & \multicolumn{3}{|c|}{ Prey species } & \multirow{2}{*}{ S.E. \pm} & \multirow{2}{*}{$\begin{array}{c}\text { C.D at } \\
5 \%\end{array}$} & \multirow{2}{*}{ C.V. $(\%)$} \\
\hline & A. gossypii & M. hirsutus & P. solenopsis & & & \\
\hline Duration of I st instar grub (days) $^{2}$ & 5.97 & 4.94 & 4.48 & 0.06 & 0.19 & 2.71 \\
\hline Total prey consumption by Ist instar grub & $54.24(7.37)$ & $10.10(3.18)$ & $7.53(2.75)$ & 0.33 & 1.02 & 3.10 \\
\hline Per day prey consumption by It $^{\text {st }}$ instar grub & $9.04(3.01)$ & $2.04(1.43)$ & $1.68(1.29)$ & 0.07 & 0.21 & 3.73 \\
\hline Duration of II ${ }^{\text {nd }}$ instar grub (days) & 5.32 & 4.51 & 4.36 & 0.03 & 0.09 & 1.69 \\
\hline Total prey consumption by II ${ }^{\text {nd }}$ instar grub & $107.06(10.35)$ & $21.09 .06(4.5)$ & $16.38(4.04)$ & 1.23 & 3.78 & 5.7 \\
\hline Per day prey consumption by II $^{\text {nd }}$ instar grub & $20.20(4.5)$ & $4.56(2.13)$ & $3.75(1.93)$ & 0.21 & 0.65 & 4.95 \\
\hline Duration of IIII ${ }^{\text {rd }}$ instar grub (days) & 8.17 & 7.48 & 6.79 & 0.07 & 0.22 & 2.13 \\
\hline Total prey consumption by III ${ }^{\text {rd }}$ instar grub & $212.50(14.57)$ & $44.11(6.64)$ & $32.06(5.66)$ & 1.56 & 4.79 & 3.62 \\
\hline Per day prey consumption by III' instar grub & $26.01(5.09)$ & $5.89(2.42)$ & $4.71(2.17)$ & 0.33 & 1.02 & 6.07 \\
\hline Duration of IV ${ }^{\text {th }}$ instar grub (days) & 8.84 & 8.09 & 7.36 & 0.05 & 0.15 & 1.51 \\
\hline Total prey consumption by IV ${ }^{\text {th }}$ instar grub & $315.20(17.75)$ & $60.77(7.79)$ & $47.33(6.78)$ & 2.11 & 6.50 & 3.35 \\
\hline Per day prey consumption by IV th instar grub & $35.65(5.98)$ & $7.51(2.73)$ & $6.43(2.53)$ & 0.35 & 1.06 & 4.68 \\
\hline Duration of Ist to IV th instar grubs (days) & 28.30 & 25.02 & 22.99 & 0.10 & 0.31 & 0.89 \\
\hline Total consumption by Ist to IV ${ }^{\text {th }}$ instar grubs & $688.93(26.25)$ & $136.08(11.67)$ & $103.38(10.17)$ & 3.47 & 10.70 & 2.51 \\
\hline
\end{tabular}

Table 3. Feeding potential of adults of $C$. montrouzieri on mealybugs and aphids

\begin{tabular}{|c|c|c|c|c|c|c|}
\hline Parameter & & Prey species & & S.E. \pm & C.D at $5 \%$ & C.V. (\%) \\
\hline & A. gossypii & M. hirsutus & P. solenopsis & & . & \\
\hline Duration of male adult (days) & 54 & 77 & 84 & 0.98 & 3.03 & 3.07 \\
\hline Total prey consumption by male adult & $770.12(27.75)$ & $402.38(20.05)$ & $383.95(19.59)$ & 4.14 & N.S. & 1.78 \\
\hline Per day prey consumption by male adult & $14.26(3.78)$ & $5.22(2.29)$ & $4.57(2.13)$ & 0.07 & 0.22 & 2.01 \\
\hline Duration of female adult (days) & 62 & 107 & 96 & 0.68 & 2.10 & 1.73 \\
\hline Total prey consumption by female adult & $917.80(30.29)$ & $589.60(24.29)$ & $476.00(21.81)$ & 4.14 & N.S. & 1.40 \\
\hline Per day prey consumption by female adult & $14.79(3.84)$ & $5.51(2.34)$ & $4.96(2.22)$ & 0.04 & 0.13 & 1.17 \\
\hline
\end{tabular}


SURWASE et al.

beetle of C. montrouzieri was reported to consume 567.60 nymphs of $M$. hirsutus in 42.77 days ( Kulkarni, 2000), 835.70 nymphs of M. hirsutus (Kulkarni 2001), 880.20 II instar nymphs of M. hirsutus or $693.40 \mathrm{II}$ instar nymphs of $P$. solenopsis (Gore 2012). Prabal Saikia and Balasubramanian (2000) reported that predatory potential of female beetle of C. montrouzieri was higher on all prey compared to the male. The order of predatory potential of female beetle on different prey insects was $A$. gossypii on cotton (92.80) A. gossypii on okra $(90.60)>$ cowpea aphid $(17.80)>$ mealybug adults (3.60).

The consumption rate of grub and adult beetle of $C$. montrouzieri was in the order of $A$. gossypii $>M$. hirsutus $>P$. solenopsis.

\section{REFERENCES}

Al Khateeb N, Raje A. 2001. A study of some biological parameters of predator, Cryptolaemus montrouzieri (Mulsant) introduced to Planococcus citri (Risso) in Syria and estimate of its predation rate in the laboratory. Arab J Plant Protection, 19(2): 131-134.

Babu TR, Azam, KM. 1987. Predation potential of Cryptolaemus montrouzieri Mulsant (Coccinellidae : Coleoptera) in relation to temperature. $J$ Res APAU, 16(2): 108-110. https://doi.org/10.1007/BF02372447

Babu TR, Azam KM. 1989. Biological control of grape mealy bug, Maconellicoccus hirsutus (Green). Indian J Pl. Prot, 17(1): 123-126.

Branigan EJ. 1916. A satisfactory method of rearing mealy bugs for use in parasite work. Monthly Bull Calif State Comm Hort, 5: 304-306.

Chacko MJ, Bhat PK, Ananda Rao LV, Deepak Singh MB, Ramanarayana EP, Sreedharan K. 1978. The use of lady bird-beetle Cryptolaemus montrouzieri for the control of Coffee mealy bugs. $J$ Coff Res, 8: 14-19.

Deokar MD. 2011. Biology, Biometrics and predatory potential of Cryptolaemus montrouzieri on Maconellicoccus hirsutus. M.Sc. (Agri.) dissertation submitted to Marathwada Krishi Vidyapeeth Parbhani (Unpublished).

Fand BB, Gautam RD, Suroshe SS. 2010. Effect of development stage and density of Phenacoccus solenopsis Tinsely (Hemiptera: Pseudococcidae) on the predatory performance of four cocinellid predators. $J$ Biol Control, 24(2): 110-115.

Fisher TW. 1963. Mass culture of Cryptolaemus and Leptomastix, natural enemies of citrus mealybug. Bull Calif Agric Exp Sta No. 797. p. 39.

Gore AB. 2012. Development and predatory potential of Cryptolaemus montrouzieri on Phenacoccus solenopsis. M.Sc. (Agri.) dissertation submitted to Marathwada Krishi Vidyapeeth Parbhani (Unpublished).

Kulkarni CG. 2001. Studies on biology of Cryptolaemus montrouzieri Mulsant and its susceptibility to some insecticides. M.Sc. (Agri.) dissertation submitted to Marathwada Krishi Vidypeeth, Parbhani (Unpublished).

Kulkarni NS. 2000. Evaluation of Australian lady-bird beetle, Cryptolaemus montrouzieri Mulsant for the control of mealy bug of custard apple. M.Sc. (Agri.) dissertation submitted to Mahatma Phule Krishi Vidyapeeth, Rahuri (Unpublished).

Mani M, Thontadarya TS. 1987a. Record of mealybug species on grapevine in Karnataka. Curr Sci, 56(22): 1192.

Mani M, Thontadarya TS. 1987b. Biological studies on grapevine mealybug predator, Scymnus craccivora Aiyer (Coccinellidae: Coleoptera). J Biol Control, 1: 89-92.

Naik MI, Manjunath M, Pradeep S, Hanumanthswamy BC. 2003. Biology of Cryptolaemus montrouzieri and its feeding potential on mulberry mealy bug. National Symposium and its Frontier Areas of Entomological Research, Nov 5-7 held at New Delhi; p. 471-485.

Saikia P, Balsubramanian A. 2000. Feeding potential and larval development of Cryptolaemus montrouzieri Muls. on aphid and mealy bug. J Agric Sci, 13(1): 8-11.

Singh SP. 1978. Propagation of coccinellid beetle for biological control of citrus and coffee mealybugs. Scientific Conference, CPA, Dec; 1978. p. 2.

Smith HS, Armitage HM. 1920. Biological control of mealy bugs in California. Calif State Dept AgriMonthly Bull, 9: $104-158$. 